\title{
Soil reinforcement by a root system and its effects on sediment yield in response to concentrated flow in the loess plateau
}

\author{
Peng $\mathrm{Li}^{{ }^{*}}$, Zhanbin $\mathrm{Li}^{1,2}$ \\ ${ }^{1}$ School of Water Resources and Hydroelectric Power, Xi’an University of Technology, Xi’an, China; \\ *Corresponding Author: lipeng74@163.com \\ ${ }^{2}$ Institute of soil and Water Conservation, Chinese Academy of Sciences, Ministry of Water Resources, Yangling, China.
}

Received 3 January 2010; revised 1 March 2011; accepted 23 March 2011.

\begin{abstract}
The importance of roots in soil conservation has long been underestimated due to a lack of systematic studies conducted to evaluate root distribution patterns and their effects on soil erosion. Current knowledge regarding root morphology and its impact on soil erosion by water is limited; therefore, detailed analysis of the role that root systems play in controlling soil erosion is needed. In this study, stratified runoff scouring at different soil depths in the field was conducted in a grassland area. The results indicated that both root biomass and soil waterstable aggregates decreased as soil depth increased at all three sites, while there was almost no change in soil bulk density at $1.3 \mathrm{~g} / \mathrm{cm}^{3}$. Sediment yields under different runoff discharge at different sites showed similar trends, and the sediment yield increased as the soil depth increased at all three sites. Further analysis revealed that close relationships existed between root biomass and the amount of water-stable aggregates and soil organic matter content, and that these factors greatly influenced soil erosion. Based on the data generated by the experiment, equations describing the relationship between sediment production at different soil depths and root biomass were determined.
\end{abstract}

Keywords: Root; Soil Properties; Soil Erosion; Sediment Yield; Loess Plateau

\section{INTRODUCTION}

The Loess Plateau is one of the most eroded areas in the world, and the resistance of loess to erosion forces has attracted a great deal of attention from researchers. A study conducted by Zhu [1] revealed that the low resistance of loess was related to its unique deposition patterns during its formation, and that it showed greatly improved resistance when vegetation was present. Due to the differences in soil properties across the profile, soil erosion exhibits various patterns, and these patterns tend to be more complex when vegetative coverage and root systems exist [2-4] Because numerous studies [5-9] evaluating the impact of vegetation characteristics on soil erosion have been conducted, it is often assumed that all aspects of vegetation have been studied. However, although many studies have investigated the effects of plant components such as leaves, stems, organic matter, roots and exudates, on soil erosion, attention has predominantly been paid to the effects of the aboveground biomass on runoff hydraulics and soil erosion $[5,10,11]$ Conversely, systematic root studies are lacking, primarily due to difficulties in direct observation of their effects [12]. Despite this lack of information, a few studies have verified that roots played a crucial role with respect to the effects of rainfall and runoff on soil erosion $[3,4,9]$. The presence of roots in soil provides mechanical reinforcement; therefore, their presence is regarded as one of the most important contributions of vegetation to soil stability $[11,13,14]$.

The reinforcement of soil resistance to erosion by plant roots can be attributed to two aspects. First, roots and root remnants physically bind soil particles, forming mechanical barriers to soil and water movement [15]. Major parameters influencing the mechanical influence of roots include root diameter, degree of bifurcation, appearance of root hairs, friction between roots and soil, and root system distribution [16]. Second, roots and root remnants excrete binding agents and form a food source for microorganisms that, in turn, produce other organic bindings $[17,18]$. These bindings increase the amount of stable soil aggregates over the long term, thereby reduc- 
ing soil erodibility [19]. Of these two aspects, the first is essential with respect to soil erosion by concentrated flow.

Several publications [3,4] describing the influence of roots on soil erosion by runoff have emphasized the need for further research in this area. To determine the effects of root systems on soil erosion quantitatively and to reveal the mechanism of rill and gully development as well as their relationship to root biomass distribution, soil properties, and sediment yield, it is necessary to study these relationships across soil profiles under field conditions. In this study, runoff scouring at different soil depths was conducted to investigate the vertical changes in soil resistance to runoff erosion forces. In addition, both vertical root distribution and related soil properties were analyzed to demonstrate the relationships among those parameters.

\section{MATERIALS AND METHODS}

\subsection{Site Conditions}

The experimental sites are located in Wangdong Watershed of the Changwu Field Experimental Station of the Institute of Soil and Water Conservation (ISWC), Chinese Academy of Sciences (CAS). The elevation of this area ranges from $950 \mathrm{~m}$ to $1225 \mathrm{~m}$. The area is subjected to a warm temperate continental seasonal climate, with an average annual temperature of $9.1^{\circ} \mathrm{C}$. The annual rainfall in the area is $584.1 \mathrm{~mm}$, most of which is concentrated between July and September. The main soil type on most sites is loess, with a clay $(<0.01 \mathrm{~mm})$ content of $25 \%$.

The dominant species on most slopes are perennial herbacious grass species of Stipa bungeana and Bothriochlon ischaemum, with similar coverage and biomass. Runoff plots on different sites were not differentiated and were considered to be in the same condition for run- off scouring (Table 1).

\subsection{Setting-Up Runoff-Scouring Plots at Different Soil Depths}

Zhou Peihu [1] and Jiang Dingsheng [20] developed runoff scouring in fields in loess regions for evaluation of soil anti-scourability. This technique is considered to be a good technology because there is no disturbance of local soil, vegetation, or topography. This technology was employed in our study during the growing season of 2002 with a runoff scouring plot size of $1 \times 4 \mathrm{~m}$. Twenty-four hours after scouring of the soil surface, sub-surface soil of 0 5 cm was removed carefully by hand, and runoff with the same former runoff discharge was conducted again. After 24 hours, the next sub-surface layer of soil of 5 10 $\mathrm{cm}$ was removed and subjected to similar runoff scouring. This process was repeated until scouring was conducted at soil depths of 5, 10, 15, 20, 25, 30, 40, and $50 \mathrm{~cm}$ (Figure 1). The runoff volume and sediment yield were measured each minute during the application of runoff.

\subsection{Root Biomass Investigation}

The soil drilling method was applied for the root investigation. For each runoff plot, eight points were distributed evenly on both sides (Figure 2) of the selected plot. Root samples from each $10 \mathrm{~cm}$ layer were collected and brought back to the laboratory and dried in an oven at $85^{\circ} \mathrm{C}$ for $24 \mathrm{~h}$ to measure the biomass. The biomass density was calculated using the following equation:

Root density $(R D)$ of certain layer $\left(\mathrm{g} / \mathrm{m}^{3}\right)$ was calculated as follows:

$$
R D=\frac{\sum_{i=1}^{n} m}{i} \times \frac{1}{\pi R^{2} h}
$$

where $R=$ the radius of the soil auger $(3.4 \mathrm{~cm}) ; h=$ the

Table 1. General conditions of runoff scouring plots by layers.

\begin{tabular}{|c|c|c|c|c|c|c|c|c|}
\hline $\begin{array}{l}\text { Plot } \\
\text { No }\end{array}$ & $\begin{array}{c}\text { Runoff discharge } \\
\text { (L/min) }\end{array}$ & $\begin{array}{c}\text { Gradient } \\
\left({ }^{\circ}\right)\end{array}$ & Cover & $\begin{array}{l}\text { Upper part bio- } \\
\text { mass }\left(\mathrm{g} / \mathrm{m}^{2}\right)\end{array}$ & $\begin{array}{l}\text { Bulk density } \\
\left(\mathrm{g} / \mathrm{cm}^{3}\right)\end{array}$ & Exposition & $\begin{array}{l}\text { Position on } \\
\text { slope }\end{array}$ & Location \\
\hline 1 & 6.5 & 20 & 0.86 & 216.21 & 1.28 & Southern & Upper & \multirow{5}{*}{$\mathrm{HBY}$} \\
\hline 2 & 8.5 & 20 & 0.81 & 200.77 & 1.25 & Southern & Upper & \\
\hline 3 & 10.5 & 20 & 0.82 & 206.59 & 1.23 & Southern & Upper & \\
\hline 4 & 12.5 & 20 & 0.81 & 208.55 & 1.24 & Southern & Upper & \\
\hline 5 & 14.5 & 20 & 0.85 & 213.74 & 1.27 & Southern & Upper & \\
\hline 6 & 10.5 & 25 & 0.82 & 212.67 & 1.27 & Southern & Middle & \multirow{3}{*}{ TSW } \\
\hline 7 & 12.5 & 25 & 0.8 & 209.55 & 1.21 & Southern & Middle & \\
\hline 8 & 14.5 & 25 & 0.81 & 209.53 & 1.29 & Southern & Middle & \\
\hline 9 & 10.5 & 8 & 0.82 & 211.69 & 1.28 & Southern & Bottom & \multirow{2}{*}{ YJS } \\
\hline 10 & 12.5 & 8 & 0.82 & 210.70 & 1.24 & Southern & Bottom & \\
\hline
\end{tabular}

Note: HBY, TSW, YJS indicate the Huangbaiwa, Tongshuwa, and Yuejiashan sites, respectively. 


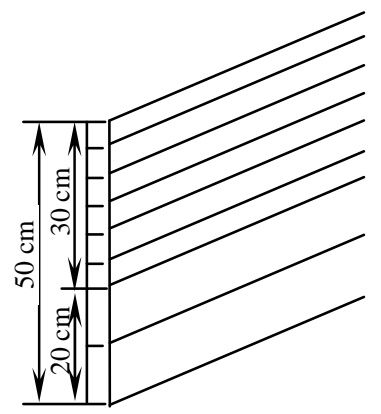

Figure 1. Cutaway view of runoff scouring plots on the soil profile.

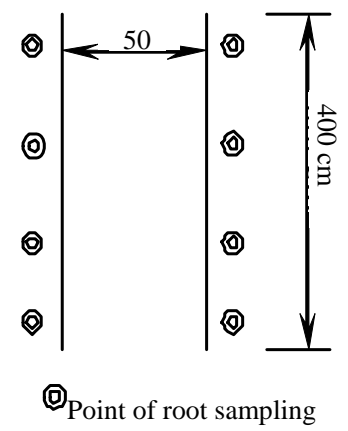

Figure 2. Sketch map of root sampling on runoff scouring plot.

thickness of the soil layer $(10 \mathrm{~cm}) ; m=$ the root weight; and $i=$ the number of sampling points

Soil properties related to soil erosion such as the soil organic matter content, water-stable aggregate content and soil bulk density were also measured.

\section{RESULTS AND DISCUSSIONS}

\subsection{Vertical Root Biomass and Soil Properties}

The vertical root biomass distributions on the three sites showed a similar decrease as soil depth increased (Figure 3). Root biomass was concentrated in the surface soil, after which it decreased to less than $0.2 \mathrm{~kg} / \mathrm{m}^{3}$ in soil below a depth of $40 \mathrm{~cm}$. There was no significant difference in the root biomass at the same soil depth at different sites, indicating that root distribution was uniform at the same depth among sampling points. Therefore, the experimental conditions can be considered to be the same for all sites. The distribution patterns of the soil organic matter content were also similar at the three sites (Figure 4). The soil organic matter content decreased as the soil depth increased, and there was no obvious difference in soil organic matter content in deep soil when compared at the same soil depth among sites.

As shown in Figure 5, the results of soil water-stable aggregates indicate that the aggregate content decreased as the soil depth increased. In addition, the aggregate content was almost the same at all three sites. Analysis

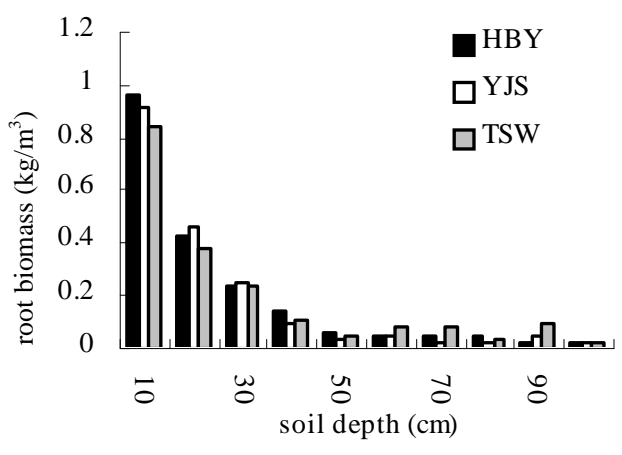

Figure 3. Root biomass distribution in natural grassland and abandoned lands of different years.

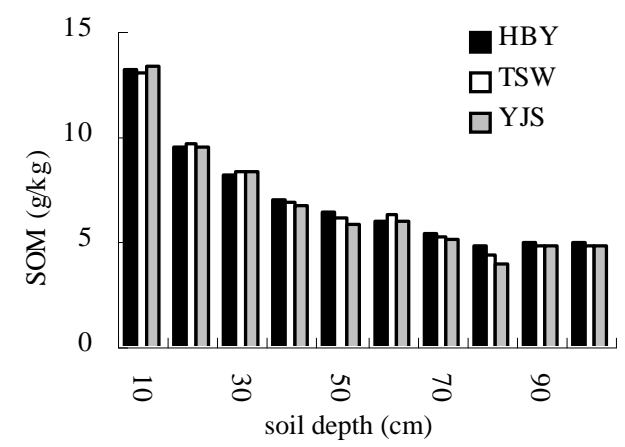

Figure 4. Vertical soil organic matter distribution patterns.

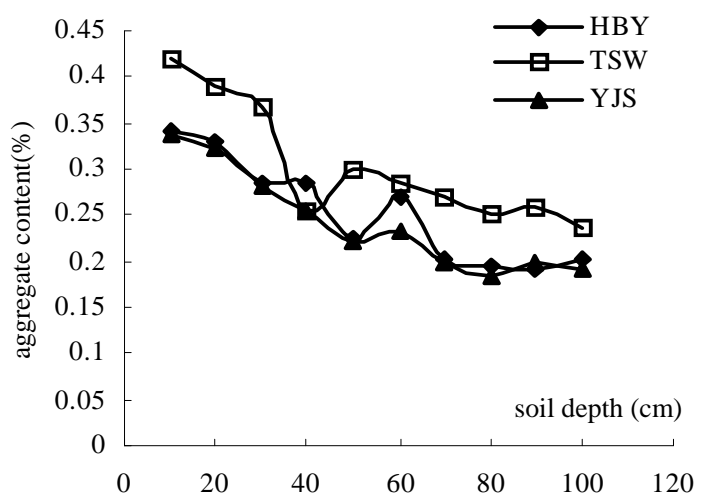

Figure 5. Vertical distribution patterns of soil aggregate content.

of the aggregate class distribution (Figure 6) revealed that there was little difference in content among small diameter classes of aggregates, but that large differences existed among aggregates with large diameter classes (2 $5 \mathrm{~mm}$ and $1 \sim 2 \mathrm{~mm}$ ). Soil bulk density, which is an important factor influencing soil erosion, was measured, and the results showed that soil bulk density varied slightly as the soil depth increased (Figure 7). However, the soil bulk density in the surface soil was almost the same $\left(1.3 \mathrm{~g} / \mathrm{cm}^{3}\right)$ at all three sites. 


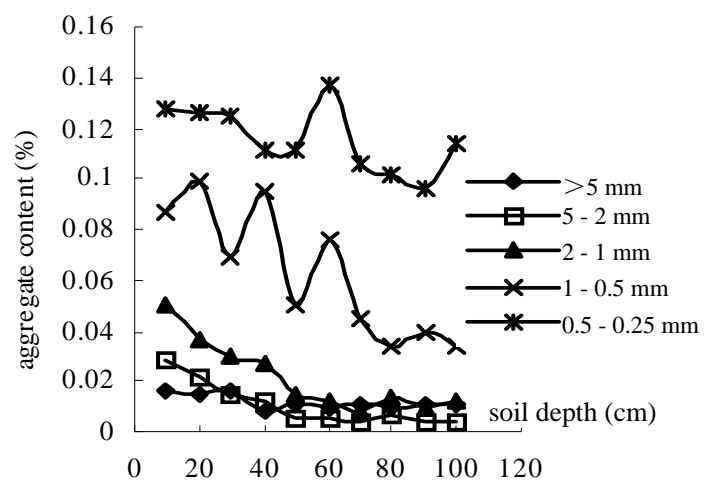

Figure 6. Vertical distribution patterns of soil aggregate content in different classes on HBY.

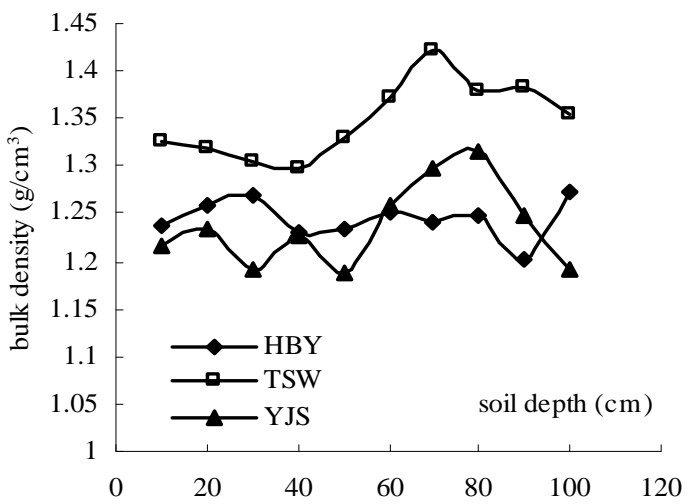

Figure 7. Vertical distribution patterns of soil bulk density.

\subsection{Sediment Yield Processes at Different Soil Depths under Different Runoff Discharges and Slope Gradients}

To avoid confusion, only sediment yield processes at soil depths of $5 \mathrm{~cm}, 15 \mathrm{~cm}, 40 \mathrm{~cm}$, and $50 \mathrm{~cm}$ are illustrated in the figures. As shown in Figure 8, the sediment yield decreased with time at all sites and tended to be stabilized two minutes after beginning the experiment. The high sediment yield in the beginning was the result of soil disturbance caused by soil division in the experiment.

Sediment yield processes under different runoff discharges at different sites demonstrated similar trends (Figure 8 and Table 2), and the sediment yield increased as soil depth increased at all three sites. Specifically, sediment yield on surface soil was similar at these sites. However, the yield increased sharply at soil depths over $30 \mathrm{~cm}$, and this change was apparently closely related to runoff discharge and slope gradient. Considering the root distribution pattern, it can be concluded that, on surface soil layer, the effect of the root system on sediment yield was dominant, but that this effect decreased as the soil depth increased. When the soil depth was greater than 40

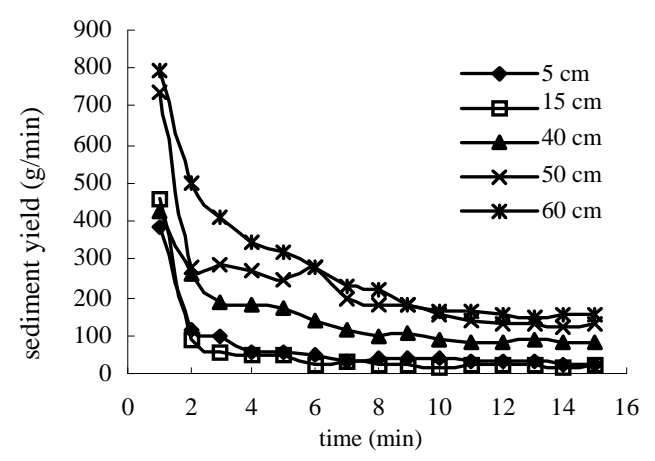

HBY- $(10.5 \mathrm{~L} / \mathrm{min})$

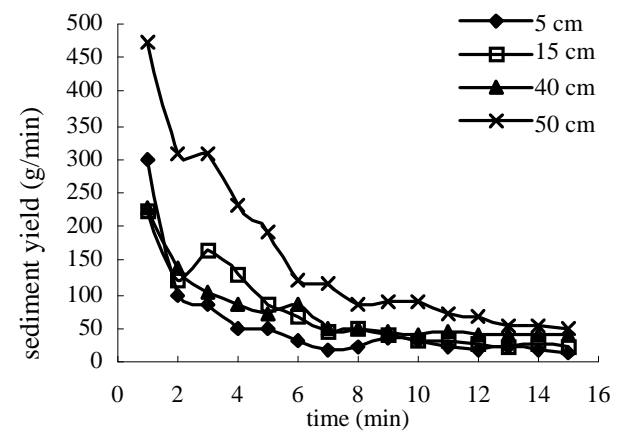

YJS- $(10.5 \mathrm{~L} / \mathrm{min})$

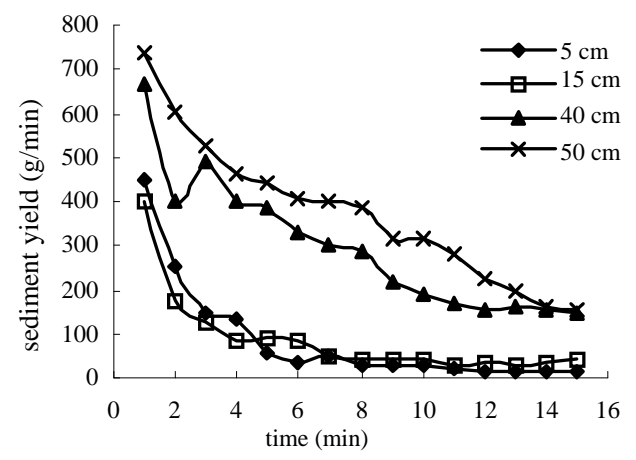

$\operatorname{TSW}\left(25^{\circ}\right)-(10.5 \mathrm{~L} / \mathrm{min})$

Figure 8. Sediment yield process at different depth and sites.

$\mathrm{cm}$, the effect of the root system on soil properties, and consequently on sediment yield, was especially limited due to its reduced distribution in deeper soil. As a result, sediment yield tended to increase as the runoff discharge and slope gradient increased. Fluctuations in sediment yield can be interpreted by the existence of animal holes and biopores of roots and their remnants.

During the runoff scouring, changes in the soil erosion forms were focused on. Sheet erosion occurred on the surface soil layer; however, as the soil depth increased, soil erosion holes appeared on the slope, and their size and number increased with depth. At a depth of $40 \sim 50$ $\mathrm{cm}$, these erosion holes tended to be connected, and sheet erosion tended to transform into rill erosion, indi- 
Table 2. Vertical sediment production on different slopes and in response to different runoff discharge.

\begin{tabular}{|c|c|c|c|c|c|c|c|c|c|c|}
\hline \multirow{2}{*}{ Location } & \multirow{2}{*}{$\begin{array}{l}\text { Runoff } \\
\text { discharge } \\
\text { (L/min) }\end{array}$} & \multicolumn{9}{|c|}{ Soil depth (cm) } \\
\hline & & $0-5$ & $5-10$ & $10-15$ & $15-20$ & $20-25$ & $25-30$ & $30-40$ & $40-50$ & $50-60$ \\
\hline \multirow{2}{*}{ YJS $8^{\circ}$} & 12.5 & 13.14 & 25.06 & 31.68 & - & 37.73 & 37.84 & 46.00 & 59.16 & - \\
\hline & 10.5 & 11.27 & 20.81 & 23.87 & - & 34.73 & 34.05 & 38.90 & 50.84 & - \\
\hline \multirow{5}{*}{$\mathrm{HBY} 20^{\circ}$} & 6.5 & 19.48 & 18.23 & 24.81 & 25.27 & 25.73 & 28.14 & 33.48 & 62.90 & - \\
\hline & 8.5 & 14.24 & 20.67 & 12.46 & 18.13 & 23.81 & 16.80 & 65.71 & 111.53 & - \\
\hline & 10.5 & 16.47 & 25.17 & 21.00 & 36.86 & 23.24 & 65.06 & 84.91 & 129.91 & 156.19 \\
\hline & 12.5 & 22.47 & 27.25 & 31.94 & 69.32 & 53.99 & 80.94 & 161.42 & 255.79 & - \\
\hline & 14.5 & 19.20 & 24.09 & 25.28 & 26.46 & 40.08 & 114.61 & 177.14 & 271.77 & - \\
\hline \multirow{3}{*}{$\operatorname{TSW} 25^{\circ}$} & 10.5 & 15.91 & 19.57 & 22.50 & 39.67 & 111.83 & 118.42 & 134.43 & 143.03 & - \\
\hline & 12.5 & 22.30 & 29.67 & 39.86 & 71.33 & 98.93 & 130.44 & 135.39 & 149.51 & - \\
\hline & 14.5 & 18.03 & 25.18 & 45.39 & 80.33 & 107.62 & 133.19 & 151.42 & 179.71 & - \\
\hline
\end{tabular}

Note: There was no runoff scouring on the soil layers with “-“due to poor control when separating layers.

cating a decrease in the resistance of soil to runoff scouring. Notably, there were some very fine roots present in these erosion holes, suggesting that not all roots improve soil resistance to runoff scouring.

\subsection{Relationship between Root Biomass and Soil Properties}

As main bridges for communication between material and energy, ecological and physiological features of the root system had a deep impact on amelioration and improvement of soil properties, especially those properties related to soil erosion. According to some former studies, the main soil properties related to erosion, including soil organic matter and water stable aggregate content, were closely related to the distribution of root systems. In this study, the relationships among root systems, soil organic matter and aggregate content were established based on experimental data.

As shown in Figure 9, as the root biomass increased, the soil organic matter content or content of soil aggregates $(1 \sim 2 \mathrm{~mm})$ increased logarithmically. The large data error that was observed may indicate that these properties in surface soil were greatly influenced by human activities, such as fire, grazing, trampling, etc., as well as by natural factors such as rainfall, freezing and thawing. The relationship between root biomass and soil properties in deep soil layers tended to be more significant, especially in areas in which the root density was lower than 0.2 $\mathrm{g} / \mathrm{cm}^{3}$. Furthermore, the relationship between root and soil properties was not linear, indicating that the existence of root biomass could only improve soil to a certain level.

\subsection{Relationship between Sediment Yield, Root Biomass and Soil Properties}

The improvement of soil properties and soil resis- tance to runoff can be attributed to a well-developed root system. As shown in Figures 10-12, there were close relationships between sediment yield and root biomass, soil organic matter content or content of water-stable aggregates. Thus, further consideration must be given to selecting indexes to reflect the effects of vegetation on soil erosion.

As the main source of energy and material in soil, the root system radically reflects the improvement of soil properties by vegetation, especially which of herbaceous vegetation with root systems primarily composed of fine roots. Those roots are more easily transformed into soil organic matter due to their shorter fibers; therefore, it is rational to select root biomass as the main index to reflect the effects of vegetation on sediment yield. As shown in Figure 11, the sediment yield per unit of runoff discharge decreases as the root biomass density increases, indicating that root biomass is effective at improving soil resistance to soil erosion forces. Following data analysis, the following equation describing the relationship between sediment production at different soil depths and root biomass was determined:

$$
Y=\frac{1}{a+b \ln x}
$$

where $Y$ is the sediment yield at different soil depths, $x$ is the root biomass, $a$ and $b$ are constants. The simulated results (Table 3) indicated that this fitting equation reflected the relationship between the root system and sediment yield well under different runoff discharges. As shown in Table 3, it is clear that the value of $a$ and $b$ decreased as the runoff discharge increased, implying that their reciprocal values may be related to soil erodibility.

When the root biomass density was greater than 0.2 $\mathrm{kg} / \mathrm{m}^{3}$, the effects of root biomass on sediment yield reduction were remarkable. In addition, when the root 

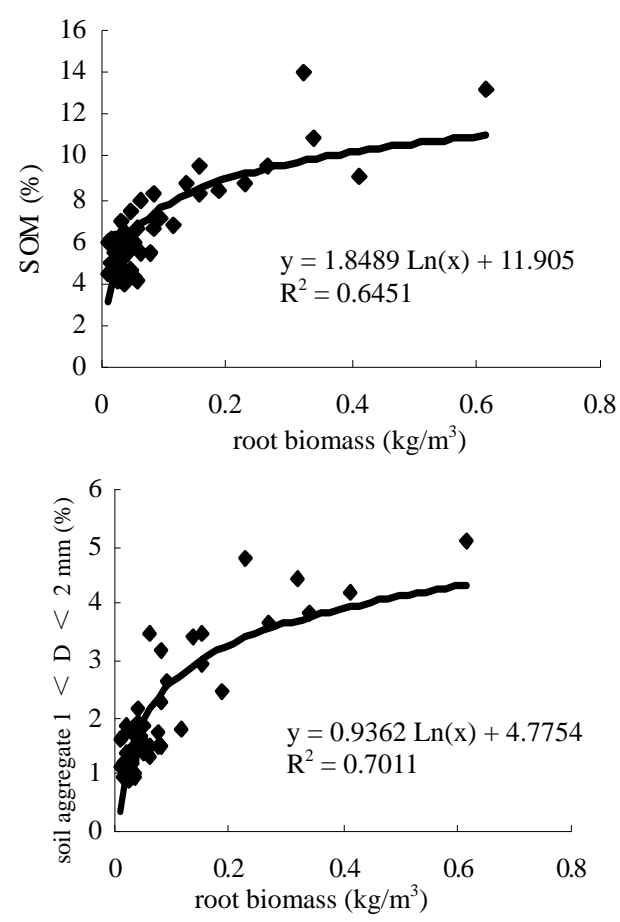

Figure 9. Relationship between root biomass and soil properties.

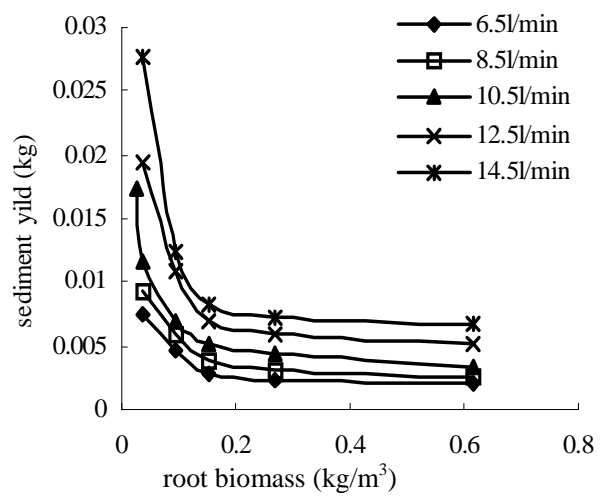

Figure 10. Relationship between sediment yield and root biomass.

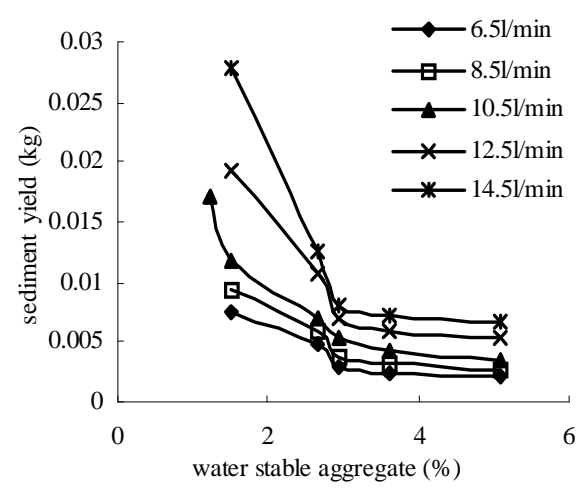

Figure 11. Relationship between sediment yield and water stable aggregate content.

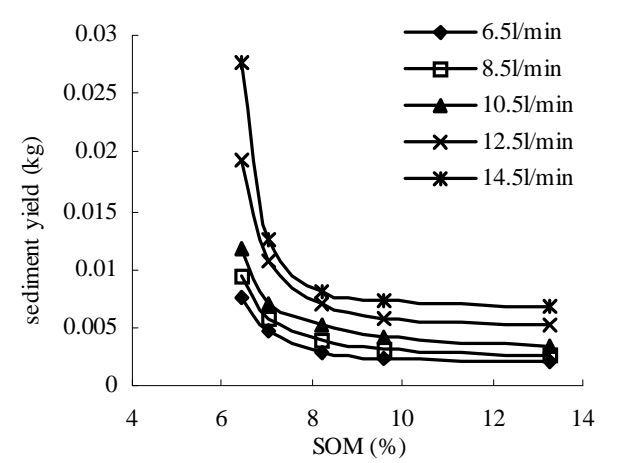

Figure 12. Relationship between sediment yield and soil organic matter content.

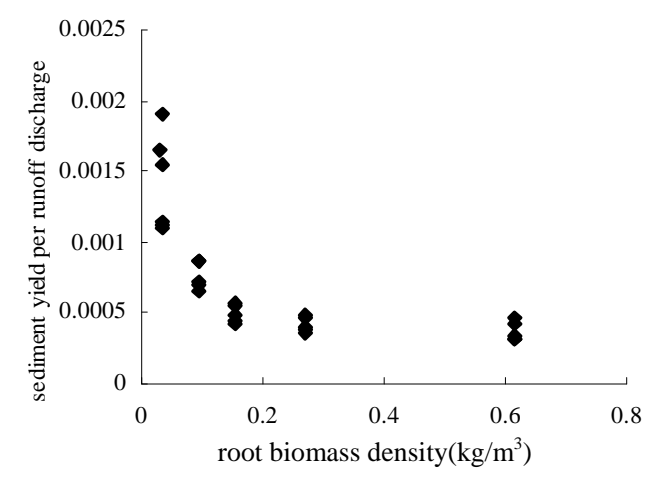

Figure 13. Relationship between root biomass and sediment yield per unit of runoff discharge.

Table3. Determination of the constants of $a$ and $b$ in the equation.

\begin{tabular}{cccccc}
\hline & $6.5 \mathrm{~L} / \mathrm{min}$ & $8.5 \mathrm{~L} / \mathrm{min}$ & $10.5 \mathrm{~L} / \mathrm{min}$ & $12.5 \mathrm{~L} / \mathrm{min}$ & $14.5 \mathrm{~L} / \mathrm{min}$ \\
\hline$a$ & 547.8126 & 411.9401 & 338.4305 & 226.8418 & 200.5907 \\
$b$ & 125.8726 & 92.8135 & 78.6954 & 53.0848 & 49.8790 \\
Standard Error & 0.0005 & 0.0005 & 0.0006 & 0.0008 & 0.0009 \\
Coefficient & 0.9817 & 0.9893 & 0.9956 & 0.9933 & 0.9958 \\
\hline
\end{tabular}

biomass distribution was below $0.2 \mathrm{~kg} / \mathrm{m}^{3}$, there was a linear relationship between root biomass and sediment yield.

Selection of appropriate root indexes has long been the subject of debate. In studies related to root physiology and ecology, root length and surface area have been chosen as indexes because they are directly related to the area in which the root and soil environment touch and they reflect the physiological functions of the root in the processes of vegetation improvement. The results of the present study imply that there is an intrinsic relationship among the root, soil organic matter and water-stable aggregates, and that root biomass turnover is the main reason for the improvement of soil organic and water-stable aggregates. Therefore, these findings indicate that root biomass is a better index than other root indexes in studies related to soil erosion. 
In addition, although there were herbaceous grass roots distributed in deep soil, there were also small, fine roots in the erosion holes. These findings indicate that not all the roots effectively improve soil resistance to erosion. Using root biomass as an index for describing the relationship between vegetation and erosion not only includes non-significant factors such as fine roots, but, more importantly, may undermine the significance of root length and surface area.

\section{CONCLUSIONS}

Many publications have discussed the impact of vegetation on soil erosion and reported that the influence of plants is mainly attributed to the aboveground biomass. Indeed, the importance of belowground biomass with respect to soil erosion by water can easily be neglected. In this study, systematic investigations of the root distribution, soil properties, and sediment yield were conducted to reveal the relationships among these factors. Based on the experiments conducted in the field, the following conclusions can be reached.

Runoff scouring of different soil depth indicated that, because of the difference in root biomass distribution in the soil profile, there was a remarkable difference in sediment yield, which emphasized the importance of reinforcement of roots in soil.

There was also a close relationship between root biomass and soil properties, including soil organic matter content and content of water stable aggregates. As the main source of material and energy, root biomass was selected as the main index to determine the effects of vegetation on sediment yield. The sediment yield by unit runoff discharge decreased as the root biomass increased. A root density of $0.2 \mathrm{~g} / \mathrm{m}^{3}$ was found to be the critical value for the sediment yield patterns.

\section{ACKNOWLEDGEMENTS}

This article was financially supported by the national natural scientific foundation (No: 41071182). In addition, the authors would like to express their appreciation to the staff of $\mathrm{Mr}$. Shen Mingyun and Mr. Zheng Liangyong for their useful suggestions and technical assistance during the study.

\section{REFERENCES}

[1] Zhou, P. and Wu C.L. (1993) Researches on the methods of soil anti-scourability on Loess Plateau. Journal of Soil and Water Conservation (in Chinese). 7, 29-34

[2] Gyssels, G. and Poesen, J. (2003) The importance of plant root characteristics in controlling concentrated flow erosion rates. Earth Surface Processes and
Landforms, 28, 371-384 doi:10.1002/esp.447

[3] Ghidey, F. and Alberts, E.E. (1997) Plant root effects on soil erodibility, splash detachment, soil strength, and aggregate stability. Transactions of the American Society of Agricultural Engineers, 40, 129-135.

[4] Li, Y., Zhu, X.-M. and Tian, J.-Y. (1991) Effectiveness of plant roots to increase the anti-scourability of soil on the Loess Plateau. Chinese Science Bulletin, 36, 2077-2082.

[5] Morgan, R.P.C. (1995) Soil Erosion and Conservation. 2nd edition, Longman Group, Harlow.

[6] Carroll, C., Merton, L. and Burger, P. (2000) Impact of vegetation cover and slope on runoff, erosion, and water quality for field plots on a range of soil and spoil materials on central Queenland coal mines. Australian Journal of Soil Research, 38, 313-327. doi:10.1071/SR99052

[7] Hoffmann, L. and Ries, R.E. (1991) Relationship of soil and plant characters to erosion and runoff on pasture and range. Journal of soil and water conservation, 46, 143-147

[8] Loch, R.J. (2000) Effects of vegetation cover on runoff and erosion under simulation rain and overland flow on a rehabilitated site on the Meandu Mine, Tarong, Queenland. Australian Journal of Soil Research, 38, 299-312. doi:10.1071/SR99030

[9] Li, P., Li, Z.B. and Zheng, L.Y. (2002) Advances in researches of the effectiveness for vegetation conserving soil and water. Research of Soil and Water Conservation (in Chinese), 9, 76-80.

[10] Thornes, J.B. (1987) The palaeoecology of erosion. In Landscapes and Culture. In: Wagstaff, J.M. Ed. Basic Blackwell, Oxford, 37-55.

[11] Morgan, R.P.C. and Rickson, R.J. (1995) Slope Stabilization and Erosion Control: A Bioengineering Approach. Chapman and Hall, Taylor \& Francis, London.

[12] Jansen, R.C. and Coelho Netto, A.L. (1999) Root systems distribution and functions in a mountainous tropical rainforest environment. Geomorphic Responses to Vegetation Changes: Problems and Remedial Work. Proceedings of the International Geographical Union, Earth Surface Processes and Landforms, John Wiley \& Sons, Ltd, 28, 371-384.

[13] Greenway, D.R. (1987) Vegetation and slope stability., In: Anderson, M.G. and Richards, K.S, Eds., Slope Stability, John Wiley \& Sons, Chichester; 187-230.

[14] Waldron, L.J. and Dakessian, S. (1981) Soil reinforcement by roots: Calculation of increased soil shear resistance from root properties. Soil Science, 132, 427-435. doi:10.1097/00010694-198112000-00007

[15] Tengbeh, G.T. (1993) The effect of grass roots on shear strength variations with moisture content. Soil Technology, 6, 387-295. doi:10.1016/0933-3630(93)90017-9

[16] Abe, K. and Ziemer, R.R. (1991) Effect of tree roots on shallow-seated landslides. USDA Forest Service General Technical Report, 22, 95-108.

[17] Reid, B.J. and Goss, M.J. (1987) Effect of living roots of different plant species on the aggregate stability of two arable soils. Journal of Soil Science, 32, 521-541. doi:10.1111/j.1365-2389.1981.tb01727.x 
[18] Cresswell, H.P. and Kirkegaard, J.A. (1995) Subsoil amelioration by plant roots-The process and evident. Australian Journal of Soil Research, 33, 221-239. doi:10.1071/SR9950221

[19] Hartman, R. and De Boodt, M. (1974) The influence of the moisture content, texture and organic-matter on the aggregation of sandy and loamy soils. Geoderma 11, 53-62. doi:10.1016/0016-7061(74)90006-8

[20] Jiang, D.S., Fan X.K. and Li X.H. (1995) Researches on vertical and horizontal patterns of soil anti-scourablity on Loess Plateau. Journal of Soil and Water Conservation, 9, 1-8. 